\title{
Physicochemical characteristics and sensory acceptability of ready-to-eat sliced frozen roast beef with partial reduction of sodium chloride
}

 \\ Luana Sanches OLIVEIRA ${ }^{3}$, Andrea Carla da Silva BARRETTO ${ }^{1 *}$
}

\begin{abstract}
Sodium chloride in meat products provides microbiological stability and desirable technological and sensory effects. Therefore, the reduction of this ingredient is a challenge for the meat industry. The objective of this study was to evaluate the physicochemical and sensory characteristics of ready-to-eat sliced frozen roast beef with partial replacement of sodium chloride by a commercial additive mostly composed of potassium chloride. The analyses performed were chemical composition, cooking yield and post defrosting loss, microbiological evaluation and sensory analysis. There was higher moisture content $(\mathrm{p}<0.05)$ in the control treatment (without the presence of the replacement additive) and all treatments were not different $(\mathrm{p} \geq 0.05)$ in the cooking yield and in post-defrosting loss. The results of microbiological analysis are according to Brazilian Legislation. The sensory evaluation showed no difference between the control treatment and the T1 treatment (with the reduction of $35 \%$ of $\mathrm{NaCl}$ ), while the $\mathrm{T} 2$ treatment (with reduction of $70 \%$ of $\mathrm{NaCl}$ ) had the lowest average values in all attributes. The study showed that the reduction of $35 \% \mathrm{NaCl}$ for commercial additive, mostly composed of potassium chloride, in roast beef is feasible since no changes were observed in sensory and technological characteristics evaluated.
\end{abstract}

Keywords: cooking loss; potassium chloride; post-defrosting loss; sensory analysis.

Practical Application: Replacing sodium chloride by a blend mostly composed of potassium chloride in ready-to-eat sliced frozen roast beef produce goods sensorial results when the replacing was $35 \%$. The cooking yield and post defrosting loss were no different among the treatments - control, replacement of $35 \% \mathrm{NaCl}$ and replacement of $70 \% \mathrm{NaCl}$. This information will help the meat industry to reduce sodium in ready-to-eat frozen meat products.

\section{Introduction}

Excessive intake of food containing high rates of saturated fats, sugars and salt are considered precursor factors for NCDs. Among them, sodium stands out as a cause for concern for public health (Iser et al., 2011). The clear relationship between excessive sodium consumption and the incidence of hypertension (Macgregor, 1997; Stamler et al., 1996) has led public healthcare regulatory agencies in various countries to recommend sodium reduction in food products (Asaria et al., 2007). It is estimated that in most of the developed countries, the daily intake of sodium chloride varies from 8 to $13 \mathrm{~g}$, which is much higher than the $5 \mathrm{~g}$ recommended by the World Health Organization (1990) as the maximum amount to be ingested daily by adults. Therefore many scientific studies have been conducted on sodium reduction in manufacturing food, especially meat products (Horita et al., 2011; Bonfim et al., 2015; Ruusunen \& Puolanne, 2005).

Meat products are widely consumed however this consumption has been criticized due to the high sodium content present in their formulations. The reduction in the sodium content added to meat products aims to develop healthier products, which necessarily implies the removal or partial replacement of sodium chloride in the formulation, which is the main source of this ion in meat products (Weiss et al., 2010; Ruusunen \& Puolanne, 2005).

In the processing of meat products, sodium chloride is used as flavoring or as a flavor enhancer, and is responsible for the texture of the final product. It also has a bacteriostatic function. Some studies indicate that reducing the salt content in meat products without the use of another preservative may shorten the shelf-life of the product. Sodium chloride, besides giving desirable sensory characteristics and assisting in the microbiological stability, also performs an important role in the processing of meat products. Sodium chloride extracts and solubilizes the myofibrillar proteins by increasing the ionic strength and promoting technological properties such as the binding power and the water holding capacity (Desmond, 2006). 
In fact, several authors have observed changes in salt penetration when replacing $\mathrm{NaCl}$ by a mixture of salts $(\mathrm{KCl}$, $\mathrm{CaCl}_{2}$ and $\mathrm{MgCl}_{2}$ ) (Blesa et al., 2008; Carraro et al., 2012). Carraro et al. (2012) verified the effect of sodium reduction and the use of herbs and spices in the quality and safety of bologna sausage. The study concluded that the replacement of $50 \% \mathrm{NaCl}$ with $\mathrm{KCl}$ by the addition of functional herbs and spices resulted in a product with satisfactory quality and microbiological safety.

Ready-to-eat foods may require specific interventions to prevent Listeria monocytogenes contamination and growth in these products, where post processing contamination is not uncommon because the pathogen is so prevalent in the environment (Thompson et al., 2008).

Roast beef is a meat product available in fast food chains and final consumer, and when it is sliced and frozen, the shelf life is increased. The replacement of sodium chloride in this product can influence some important physicochemical properties and sensorial acceptance. Therefore, the study aimed to evaluate the effect of replacing $35 \%$ and $70 \%$ added $\mathrm{NaCl}$ in brine by a commercial additive mainly composed of potassium chloride on the physicochemical properties and sensory acceptance of ready-to-eat roast beef.

\section{Materials and methods}

All three treatments were produced at Minerva Fine Foods, a meat processing and packaging plant, in the town of Barretos, Brazil. The sodium chloride replacement used in the study was NS-969-435-4 Givaudan', composed of potassium chloride, dipotassium phosphate, natural flavor, potato maltodextrin, sodium glutamate, sodium chloride, lactic acid, potassium citrate, tricalcium phosphate, silicon dioxide, disodium guanylate, reaction flavoring, disodium inosinate, tartaric acid and natural flavoring.

The raw material was obtained at Frigorifico Minerva in frozen package of 20 kilos. It was thawed at refrigerated conditions $\left(0\right.$ to $4^{\circ} \mathrm{C}$ ) overnight or until reached $4^{\circ} \mathrm{C}$ in raw material. Table 1 presents the formulations of the three treatments $(\mathrm{C}, \mathrm{T} 1$ and $\mathrm{T} 2)$.

Table 1. Roast beef treatments.

\begin{tabular}{lccc}
\hline & $\mathrm{C}(\%)$ & $\mathrm{T} 1(\%)$ & $\mathrm{T} 2(\%)$ \\
\hline Beef top round & 70.0 & 70.0 & 70.0 \\
Water & 25.11 & 25.11 & 25.11 \\
Sodium Chloride & $\mathbf{1 . 3 5}$ & $\mathbf{0 . 8 8}$ & $\mathbf{0 . 4 0}$ \\
Commercial additive & - & $\mathbf{0 . 4 7}$ & $\mathbf{0 . 9 5}$ \\
mainly composed of & & & \\
potassium chloride & & & \\
Milk Powder & 1.26 & 1.26 & 1.26 \\
Onion Powder & 0.75 & 0.75 & 0.75 \\
Sodium Tripolyphosphate & 0.63 & 0.63 & 0.63 \\
Garlic Powder & 0.45 & 0.45 & 0.45 \\
Beef flavour seasoning & 0.33 & 0.33 & 0.33 \\
Hydrolyzed protein & 0.06 & 0.06 & 0.06 \\
Sugar & 0.06 & 0.06 & 0.06 \\
Total & 100.0 & 100.0 & 100.0 \\
\hline
\end{tabular}

The replacement of sodium chloride by a commercial additive mostly composed of potassium chloride was in the brine at 35\% (T1 treatment) and 70\% (T2 treatment), while the standard control treatment $(\mathrm{C})$ had the standard formulation (no replacement of $\mathrm{NaCl}$ ). Beef top rounds (95\% to $97 \%$ lean) were injected (Injection Intermec AMF300, São Caetano do Sul, Brazil) at a temperature of $1.5^{\circ} \mathrm{C}$ and vacuum tumbled (Tumbler Challenge RMF - MM-05, Missouri, USA) at $150 \mathrm{mbar}$ at 7 revolutions per minute for 40 minutes. The treatments were put in cooking bags (polythene high density roasting bags - no vacuum) (Plasmel, Cuiabá, Brazil) and cooked for 3 hours and 30 minutes at $90{ }^{\circ} \mathrm{C}$ (oven Rational SelfCooking Center 201, Rational Brazil, São Paulo, Brazil). After cooking, the treatments were cooled to $4^{\circ} \mathrm{C}$. The treatments were removed from the bags and cut into $3 \mathrm{~mm}$ slices.

The slices were packaged in 500 gram portions (packing Nylon polyethylene Itap Bemis, Dixie Toga, Valinhos, Brazil) and were frozen at $-25^{\circ} \mathrm{C}$, and kept at $-18{ }^{\circ} \mathrm{C}$ during the entire study in the Meat Laboratory of Engineering and Technology Department at the São Paulo University in São José do Rio Preto, SP (UNESP-SJRP).

\subsection{Physical and chemical analysis}

The moisture, ash and protein were analyzed according to Horwitz et al. (2007). The quantification of fat was performed according to Bligh \& Dyer (1959). The calculation of the cooking yield was done during the processing of the treatment samples. The cooking yield was calculated as the percentage difference in weight between the injected raw beef top round and the cooked sample. In determining the post-defrosting loss, the samples were weighed before and after thawing at $4{ }^{\circ} \mathrm{C}$ for $48 \mathrm{~h}$. The post-defrosting loss was calculated as the sample weight of the thaw exudate drained liquid as a percentage of the weight of the frozen sample. All the above-mentioned analyses were performed in triplicate.

\subsection{Microbiological analysis}

The treatment samples, still in their original packaging were thawed for 24-48 hours under refrigeration at 2 to $4{ }^{\circ} \mathrm{C}$ temperature, on third day shelf life. For sequential dilutions, $25 \mathrm{~g}$ slice samples were ascetically taken from the package. This material was placed in sterile bags (Nasco) $225 \mathrm{~mL}$ sterilized peptone water solution at $0.1 \%(\mathrm{w} / \mathrm{w})$ (Merck) added and homogenized in a Stomacher (Marconi) for $2 \mathrm{~min}$ at 100rpm at room temperature. The presence of Salmonella was determined using a rapid pre-enrichment method (A.O.A.C. 2003.09) (Horwitz et al., 2007), using the BAX $^{\infty}$ System (Qualicon - Dupont), with pre-enrichment of the sample produced from the incubation of the $10^{-1}$ dilution for 18 to $24 \mathrm{~h}$ at $35^{\circ} \mathrm{C}$.

Coagulase-positive staphylococci were identified following the A.O.A.C. 2003.07 method (Horwitz et al., 2007) using Petrifilm ${ }^{\text {mot }}$ Staph Express plates (3M Company), with samples incubated at temperatures between 35 and $37^{\circ} \mathrm{C}$ for $24 \pm 2 \mathrm{~h}$. When there was the formation of different types of colonies, confirmation was carried out with Petrifilm ${ }^{\mathrm{m} w}$ Staph Express disk (3M Company) 
Thermotolerant coliforms were identified following the A.O.A.C. 998.08 method (Horwitz et al., 2007). After inoculation, samples were kept at $45 \pm 1{ }^{\circ} \mathrm{C}$, for $24 \pm 2 \mathrm{~h}$ in order to verify the formation of specific colonies.

Listeria monocytogenes was determined using a rapid pre-enrichment method (A.O.A.C. 970801) (Horwitz et al., 2007) employing BAX ${ }^{\circledR}$ System (Qualicon - Dupont), with pre-enrichment of the sample by the incubation of the $10^{-1}$ dilution between 35 and $37^{\circ} \mathrm{C}$ for $24 \pm 2 \mathrm{~h}$. In ready-to-eat foods is important require the specific interventions, to prevent Listeria monocytogenes contamination (Thompson et al., 2008)

Except for the Salmonella and Listeria, all the results were expressed in Log CFU/g of sample after the identification and enumeration of the microorganisms being evaluated.

\subsection{Sensory analysis}

An affective test was used for the sensory analysis, all the treatments were labelled with 3-digit random numbers and served monadically in random order to assessors in individual booths. Sixty-eight untrained assessors (meat products consumers) evaluated the roast beef, in single cabins in the Sensory Analysis Laboratory of the Food Engineering and Technology Department at UNESP-SJRP. A hedonic test was carried out using 9-point scales in which the assessors evaluated different attributes: taste, juiciness, color and overall acceptability according to Meilgaard et al. (1999). The sensory analysis was performed 20 days after the production date. All the treatment samples were thawed at $4{ }^{\circ} \mathrm{C}$. This study was approved by the Research Ethics Committee of the Instituto de Biociências, Letras e Ciências Exatas, São Paulo State University (UNESP), São José do Rio Preto Campus (Opinion Report 864.959).

The data were analyzed using analysis of variance - ANOVA, and the differences between the average results were evaluated using the Tukey test at a confidence level of 5\%. The software used was MINITAB v.16 Statistical Software.

\section{Results and discussion}

The results of the chemical composition analysis, the average cooking yield and post defrosting loss in the three treatments are presented in Table 2.

In relation to moisture, there was a difference $(\mathrm{p}<0.05)$ among the treatments, where the control $\mathrm{C}$ treatment was moister $(\mathrm{p}<0.05)$, probably due the quantity of sodium chloride. According to Galvão et al. (2014) sodium chloride is responsible for increasing the ionic strength in the meat matrix and improving various functional properties, including water binding. The T2 treatment presents significantly lower $(\mathrm{p}<0.05)$ fat content, probably due to difference in the raw materials (beef top round) used. There were differences among the treatments with regard to ash, when the added sodium chloride was decreased, the ash decreased. Probably the salt substitute contains less minerals that the salt itself. There were no differences among the treatments in protein because the raw material used was similar for all the treatments.
For the treatments with replacement of $35 \%$ and $70 \%$ of added $\mathrm{NaCl}$ ( $\mathrm{T} 1$ and $\mathrm{T} 2$ respectively), cooking yields did not differ $(p>0.05)$ significantly from the control treatment (C). Regarding the post-defrosting loss, there was also no difference ( $p>0.05)$ among treatments (Table 2). McGough et al. (2012) also demonstrated that frankfurters with sodium reduction produced no differences for purge levels and processing yields. The study reported by Choi et al. (2014) on frankfurter sausages showed no significant effect on cooking loss in the level of $\mathrm{NaCl}$ reduction (addition level of $1.2 \%$ ).

The results of the microbiological analysis are reported in Table 3. All the results are according to Brazilian Legislation RDC n.12 (Brasil, 2001).

The results of the sensory evaluation in the acceptance test are shown in Table 4 . The T1 treatment, with replacement of $35 \%$ added $\mathrm{NaCl}$ did not differ $(\mathrm{p}>0.05)$ from the $\mathrm{C}$ treatment

Table 2. Average values ( \pm standard deviation) of the percentage composition of the treatments, cooking yield and post defrosting loss.

\begin{tabular}{lrrr}
\hline & \multicolumn{1}{c}{ C (\%) } & \multicolumn{1}{c}{ T1 (\%) } & \multicolumn{1}{c}{ T2 (\%) } \\
\hline Moisture & $70.64 \pm 0.18^{\mathrm{a}}$ & $68.86 \pm 0.05^{\mathrm{b}}$ & $67.32 \pm 0.21^{\mathrm{c}}$ \\
Ashes & $2.63 \pm 0.02^{\mathrm{a}}$ & $2.49 \pm 0.04^{\mathrm{b}}$ & $2.02 \pm 0.01^{\mathrm{c}}$ \\
Protein & $26.65 \pm 1.39^{\mathrm{a}}$ & $25.42 \pm 0.25^{\mathrm{a}}$ & $25.62 \pm 0.32^{\mathrm{a}}$ \\
Fat & $2.44 \pm 0.04^{\mathrm{a}}$ & $2.47 \pm 0.01^{\mathrm{a}}$ & $1.87 \pm 0.10^{\mathrm{b}}$ \\
Cooking yield & $63.89 \pm 3.00^{\mathrm{a}}$ & $62.93 \pm 3.09^{\mathrm{a}}$ & $62.16 \pm 0.81^{\mathrm{a}}$ \\
Post defrosting loss & $1.75 \pm 1.41^{\mathrm{a}}$ & $1.22 \pm 0.21^{\mathrm{a}}$ & $0.64 \pm 0.52^{\mathrm{a}}$ \\
\hline
\end{tabular}

Averages followed by the same letter in the same line do not show significant difference $(\mathrm{p} \leq 0.05)$ in the Tukey test. C - standard control treatment; T1 - with replacement of $35 \%$ added $\mathrm{NaCl} ; \mathrm{T} 2$ - with replacement of $70 \%$ added $\mathrm{NaCl}$.

Table 3. Microbiological analyses (log CFU/g) of roast beef.

\begin{tabular}{|c|c|c|c|c|}
\hline & $\begin{array}{c}\text { Limit } \\
\text { Brazilian } \\
\text { Legislation * }\end{array}$ & $\mathrm{C}$ & T1 & T2 \\
\hline $\begin{array}{l}\text { Coliforms } \\
45^{\circ} \mathrm{C}\end{array}$ & 3.0 & $<1.0$ & $<1.0$ & $<1.0$ \\
\hline $\begin{array}{l}\text { Staphylococcus } \\
\text { coagulase-positive }\end{array}$ & 3.48 & $<1.0$ & $<1.0$ & $<1.0$ \\
\hline $\begin{array}{l}\text { Clostridium Sulfito } \\
\text { Redutores a } 46^{\circ} \mathrm{C}\end{array}$ & $2.7 \mathrm{UFC} / \mathrm{g}$ & $<1.0$ & $<1.0$ & $<1.0$ \\
\hline Salmonella spp & absent/25g & absent $/ 25 \mathrm{~g}$ & absent $/ 25 \mathrm{~g}$ & absent $/ 25 \mathrm{~g}$ \\
\hline $\begin{array}{l}\text { Listeria } \\
\text { monocytogenes }\end{array}$ & absent $/ 25 \mathrm{~g}$ & absent $/ 25 \mathrm{~g}$ & absent $/ 25 g$ & absent/25g \\
\hline
\end{tabular}

Table 4. Average values ( \pm standard deviation) of the sensory evaluation.

\begin{tabular}{lccc}
\hline & $\mathrm{C}$ & $\mathrm{T} 1$ & T2 \\
\hline Taste & $7.53 \pm 1.24^{\mathrm{a}}$ & $6.91 \pm 1.74^{\mathrm{a}}$ & $5.90 \pm 1.71^{\mathrm{b}}$ \\
Juiciness & $7.40 \pm 1.29^{\mathrm{a}}$ & $7.06 \pm 1.46^{\mathrm{a}}$ & $5.68 \pm 1.95^{\mathrm{b}}$ \\
Color & $6.85 \pm 1.66^{\mathrm{a}}$ & $6.57 \pm 1.65^{\mathrm{a}}$ & $5.71 \pm 2.03^{\mathrm{b}}$ \\
Global acceptance & $7.04 \pm 1.42^{\mathrm{a}}$ & $6.77 \pm 1.74^{\mathrm{a}}$ & $5.85 \pm 1.76^{\mathrm{b}}$ \\
\hline
\end{tabular}

Averages followed by the same letter in the same line do not show significant difference $(\mathrm{p} \leq 0.05)$ in the Tukey test. C - standard control treatment; T1 - with replacement of $35 \%$ added $\mathrm{NaCl} ; \mathrm{T} 2$ - with replacement of $70 \%$ added $\mathrm{NaCl}$. 
in any of the measured sensory attributes. In relation to the $\mathrm{T} 2$ treatment, with the replacement of $70 \%$ added $\mathrm{NaCl}$, there was a decrease $(\mathrm{p}<0.05)$ in average scores compared to the other treatments. Galvão et al. (2014) worked with turkey ham with reduced salt content and they concluded that $30 \%$ of salt reduction did not influence consumer acceptance despite the fact that the consumers characterized the formulations tested as less salty and less seasoned than the control (with $2 \%$ of refined salt). Possibly roast beef represents the category of meat products in which the salt is used more for flavor and less for functionality.

It is important to explain that the sodium reduction in the final treatments (T1 and T2) was smaller than the values reported for the replacement of added sodium chloride, since there are other ingredients in the formulation of brine that contain sodium, and the level of injection was $30 \%$.

\section{Conclusion}

It is possible to replace $\mathrm{NaCl}$ with a commercial additive mostly composed of potassium chloride in roast beef without impairing the cooking yield and post-defrosting loss. Replacement of $35 \%$ of added $\mathrm{NaCl}$ in brine by a substitute mainly composed of potassium chloride in roast beef is possible without sensory changes in the final product (with a $30 \%$ level of injection).

\section{Acknowledgements}

The authors are grateful to the Minerva Fine Foods company and CAPES (Coordenação de Aperfeiçoamento de Pessoal de Nível Superior) for their financial support.

\section{References}

Asaria, P., Chisholm, D., Mathers, C., Ezzati, M., \& Beaglehole, R. (2007). Chronic disease prevention: health effects and financial costs of strategies to reduce salt intake and control tobacco use. Lancet, 370(9604), 2044-2053. http://dx.doi.org/10.1016/S01406736(07)61698-5. PMid:18063027.

Blesa, E., Aliño, M., Barat, J. M., Grau, R., Toldrá, F., \& Pagán, M. J. (2008). Microbiology and physico-chemical changes of dry-cured ham during the post-salting stage as affected by partial replacement of $\mathrm{NaCl}$ by other salts. Meat Science, 78(2), 135-142. http://dx.doi. org/10.1016/j.meatsci.2007.07.008. PMid:22062103.

Bligh, E. G., \& Dyer, W. J. A. (1959). Rapid method of total lipid extraction and purification. Canadian Journal of Biochemistry and Physiology, 37(8), 911-917. http://dx.doi.org/10.1139/o59-099. PMid:13671378.

Bonfim, R. C., Machado, J. S, Mathias, S. P., \& Rosenthal, A. (2015). Aplicação de transglutaminase microbiana em produtos cárneos processados com teor reduzido de sódio: Revisão bibliográfica. Ciência Rural, 45(6), 1133-118. http://dx.doi.org/10.1590/0103$8478 \mathrm{cr} 20131440$.

Brasil, Ministério da Saúde, Agência Nacional de Vigilância Sanitária. (2001, January 10). Aprova o Regulamento Técnico sobre padrões microbiológicos para alimentos (Resolução RDC n ${ }^{\circ} 12$, de 02 de janeiro de 2001). Diário Oficial [da] República Federativa do Brasil.

Carraro, C. I., Machado, R., Espindola, V., Campagnol, P. C. B., \& Pollonio, M. A. R. (2012). The effect of sodium reduction and the use of herbs and spices on the quality and safety of bologna sausage. Food Science and Technology, 3(2), 289-295. http://dx.doi. org/10.1590/S0101-20612012005000051.
Choi, Y. M., Jung, K. C., Jo, H. M., Nam, K. W., Choe, J. H., Rhee, M. S., \& Kim, B. C. (2014). Combined effects of potassium lactate and calcium ascorbate as sodium chloride substitutes on the physicochemical and sensory characteristics of low-sodium frankfurter sausage. Meat Science, 96(1), 21-25. http://dx.doi.org/10.1016/j.meatsci.2013.06.022. PMid:23896133.

Desmond, E. (2006). Reducing salt: a challenge for the meat industry. Meat Science, 74(1), 188-196. http://dx.doi.org/10.1016/j. meatsci.2006.04.014. PMid:22062728.

Galvão, M. T. E. L., Moura, D. B., Barretto, A. C. S., \& Pollonio, M. A. R. (2014). Effects of micronized sodium chloride on the sensory profile and consumer acceptance of turkey ham with reduced sodium content. Food Science and Technology, 34(1), 189-194. http://dx.doi. org/10.1590/S0101-20612014005000009.

Horita, C. N., Morgano, M. A., Celeghini, R. M. S., \& Pollonio, M. A. R. (2011). Physicochemical and sensory properties of reduced-fat mortadella prepared with blends of calcium, magnesium and potassium chloride as partial substitutes for sodium chloride. Meat Science, 89(4), 426-433. http://dx.doi.org/10.1016/j.meatsci.2011.05.010. PMid:21645975.

Horwitz, W., Latimer, G.W., \& Association of Official Analytical Chemistry - AOAC. (2007). Official Methods of Analysis (18th ed.). Gaithersburg: AOAC International.

Iser, B. P. M., Claro, R. M., De Moura, E. C., Malta, D. C., \& Morais, O. L. No.(2011). Fatores de risco e proteção para doenças crônicas não transmissíveis obtidas por inquérito telefônico. Revista Brasileira de Epidemiologia, 14(1), 90-112. http://dx.doi.org/10.1590/S1415790X2011000500010. PMid:22002146.

Macgregor, G. A. (1997). Salt-more adverse effects. American Journal of Hypertension, 10(4), 37-41. http://dx.doi.org/10.1016/S08957061(97)00072-1. PMid:9160778.

McGough, M. M., Sato, T., Rankin, S. A., \& Sindelar, J. J. (2012). Reducing sodium levels in frankfurters using a natural flavor enhancer. Meat Science, 91(2), 185-194. http://dx.doi.org/10.1016/j. meatsci.2012.01.018. PMid:22330943.

Meilgaard, M., Civille, G. V., \& Carr, B. T. (1999). Sensory evolution techniques (3rd ed.). Boca Raton: CRC Press. $</$ bok $>$.

Ruusunen, M., \& Puolanne, E. (2005). Reducing sodium intake from meat products. Meat Science, 70(3), 531-541. http://dx.doi.org/10.1016/j. meatsci.2004.07.016. PMid:22063751.

Stamler, J., Caggiula, A., Grandits, G. A., Kjelsberg, M., \& Cutler, J. A. (1996). Relationship to blood pressure of combinations of dietary macronutrients. Findings of the multiple risk factor intervention trial (MRFIT). Circulation, 94(10), 2417-2423. http://dx.doi. org/10.1161/01.CIR.94.10.2417. PMid:8921782.

Thompson, R. L., Carpenter, C. E., Martini, S., \& Broadbent, J. R. (2008). Control of Listeria monocytogenes in ready-to-eat meats containing sodium levulinate, sodium lactate, or a combination of sodium lactate and sodium diacetate. Journal of Food Science, 73(5), M329-M244. http://dx.doi.org/10.1111/j.1750-3841.2008.00786.x. PMid:18577007.

Weiss, J., Gibis, M., Schuh, V., \& Salminen, H. (2010). Advances in ingredient and processing systems for meat and meat products. Meat Science, 86(1), 196-213. http://dx.doi.org/10.1016/j.meatsci.2010.05.008. PMid:20619800.

World Health Organization - WHO. (1990). Diet, nutrition and the prevention of chronic diseases (WHO Technical Report Series, No. 916). Geneva: WHO. 